\title{
DIFFERENTIAL ASSESSMENT AND AGRICULTURAL LAND USE IN THE SOUTH
}

\author{
Rod F. Ziemer, John R. Stoll, \\ Robert Kao, and John C. Bergstrom*
}

\section{Introduction}

Differential or use-value assessment laws usually have two primary objectives: 1) to provide tax relief on eligible land and 2) to decrease the rate of conversion of eligible land to non-eligible uses. In this paper, our objective is to evaluate the effect of differential assessment legislation on conversion of eligible land to other uses in the Southern region. Recent studies have argued that differential assessment has been ineffective in preventing the conversion of agricultural land to nonagricultural uses (Berry and Plaut; Hady and Sibold; Mark and Yamauchi; NALS). In general, our results support this viewpoint.

The three types of differential assessment programs that have been adopted in the South are: preferential assessment, deferred taxation, and restrictive agreements. The present laws and their provisions for 13 Southern states are discussed at length in a recent work by Rodgers and Williams. Other summaries of the provisions and major characteristics of state differential assessment laws are also available (Coughlin et al.; Hady and Sibold; Keene et al.).

In this paper, we develop an econometric model of agricultural land use similar to that used by White and Fleming. The model is predicated on the theory of land rents, to evaluate the impact of differential assessment on conversion of eligible land. Organization of the paper is as follows. First, theoretical considerations are addressed. Second, an empirical model is proposed and statistical considerations are discussed. Next, the data for the analysis are described. Results and implications of the model are then discussed. Finally, some concluding remarks are offered.

\footnotetext{
*Ziemer is a former Assistant Professor (deceased), Stoll is Assistant Professor, Kao and Bergstrom are Research Associates, Department of Agricultural Economics, Texas A\&M University. The research upon which this work is based was supported by the Southern Rural Development Center and the Texas Agricultural Experiment Station. This is technical article TA-19310.
}

\section{Theoretical Considerations}

For the rational landowner, a land use decision involves choosing that particular land use that offers the greatest return. Returns to land are often expressed in terms of land rent defined as that portion of total returns that accrues or should accrue to land for its use in production (Barlowe, pp. 162-169). Land rent is sometimes expressed as a function of use-capacity. Land use-capacity refers to "the relative ability of a given unit of land resource to produce a surplus of returns and/or satisfactions above cost of utilization"' (Barlow, p. 14).

For a given land use, such as cropland, lower use-capacity is associated with higher production costs for a given output. Thus, lower usecapacity means lower land rent. Following the logic used by Barlowe and others, we can graphically express the relationship between land rent and use-capacity as a land rent profile. A hypothetical land rent profile for cropland is shown in Figure 1. Land $\mathrm{L}_{1}$ has the highest available use capacity while Land $\mathrm{L}_{2}$, has a lower use-capacity, and Land $\mathrm{L}_{3}$ a still lower use-capacity. Land $\mathrm{L}_{4}$ is so barren or unsuitable for cropland due to transportation and production costs that its land rent is zero.

If we consider land rent profiles for land uses other than cropland, we can establish a simple static framework to explain the allocation of land among competing land uses. Hypothetical land rent profiles are shown in Figure 2 for three competing land uses: urban and other development (A), agriculture (B), and forestry (C). The points a and b in Figure 2 represent intersections of the intensive margins, or land rent profiles, for the three land uses $\mathrm{A}, \mathrm{B}$, and C. These points are sometimes referred to as margins of transference since they represent use-capacity levels at which a land use transference occurs. For example, for any land with use-capacity greater than that for land $L_{2}$, the landowner would choose development, land use A. However, if use-capacity is less than that for $L_{2}$, greater rents are achieved by land use $B$, agriculture. Finally, for use-capacities less 


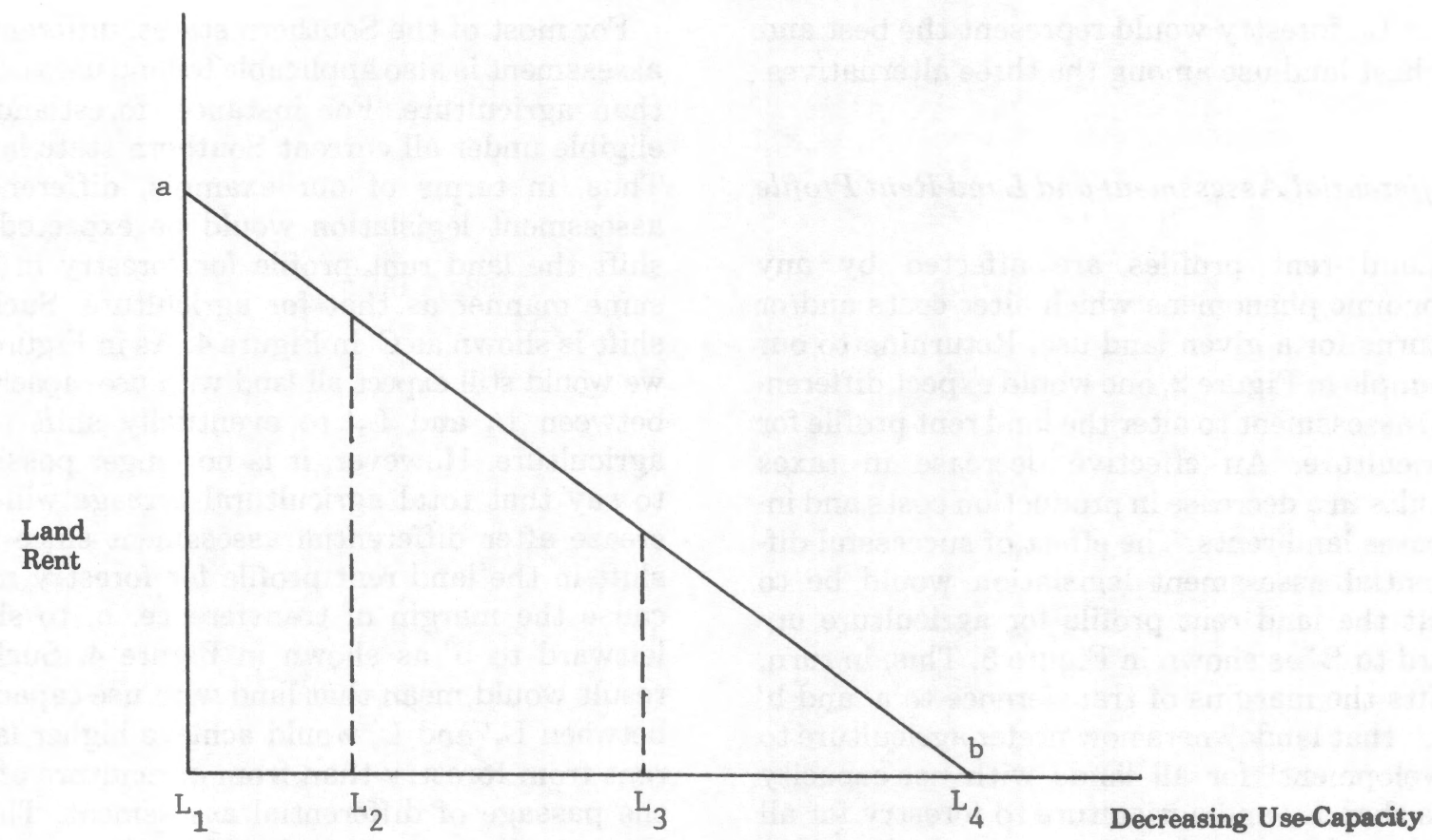

Figure 1. Hypothetical Land Rent Profile for Cropland.

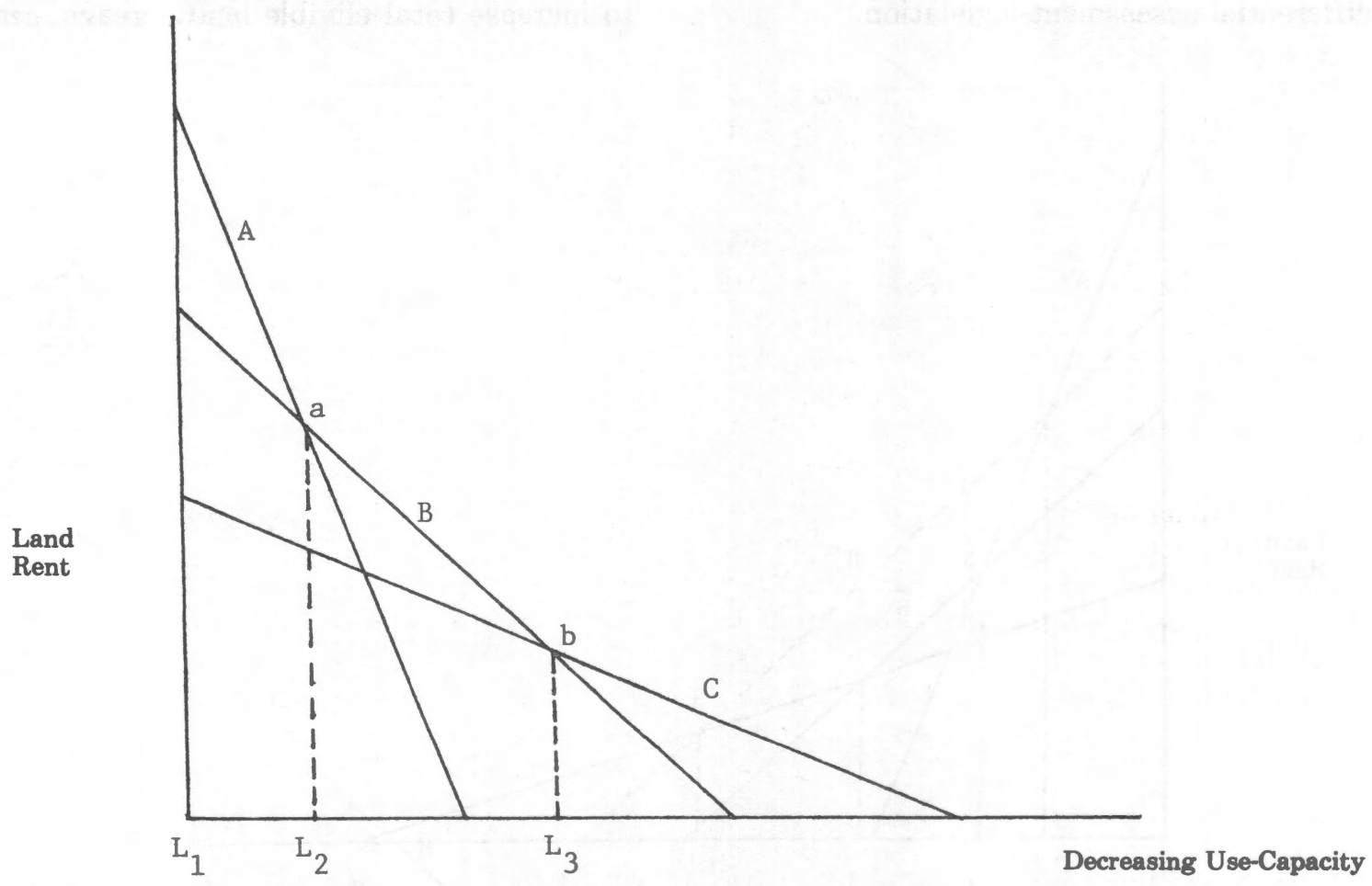

Figure 2. Land Rent Profiles for Competing Land Uses. 
than $L_{3}$, forestry would represent the best and highest land use among the three alternatives.

\section{Differential Assessment and Land Rent Profile}

Land rent profiles are affected by any economic phenomena which alter costs and/or returns for a given land use. Returning to our example in Figure 2, one would expect differential assessment to alter the land rent profile for agriculture. An effective decrease in taxes results in a decrease in production costs and increases land rents. The effect of successful differential assessment legislation would be to shift the land rent profile for agriculture upward to B' as shown in Figure 3. This, in turn, shifts the margins of transference to $a^{\prime}$ and $b^{\prime}$ such that landowners now prefer agriculture to development ${ }^{1}$ for all lands with use-capacity less than $\mathrm{L}_{2}{ }^{\prime}$ and agriculture to forestry for all lands with use-capacity greater than $\mathrm{L}_{3}$ '. Hence, given sufficient time for information and market adjustments, one would expect to see an increase in agricultural land acreage relative to competing land uses after passage of differential assessment legislation.
For most of the Southern states, differential assessment is also applicable to land uses other than agriculture. For instance, forestland is eligible under all current Southern state laws. Thus, in terms of our example, differential assessment legislation would be expected to shift the land rent profile for forestry in the same manner as that for agriculture. Such a shift is shown as C' in Figure 4. As in Figure 3, we would still expect all land with use-capacities between $L_{2}$ and $L_{2}^{\prime}$ to eventually shift into agriculture. However, it is no longer possible to say that total agricultural acreage will increase after differential assessment since the shift in the land rent profile for forestry may cause the margin of transference, $b$, to shift leftward to b' as shown in Figure 4. Such a result would mean that land with use-capacity between $\mathrm{L}_{3}{ }^{\prime}$ and $\mathrm{L}_{3}$ would achieve higher land rent from forestry than from agriculture after the passage of differential assessment. Thus, the net effect on agricultural land acreage is not unambiguously clear although total eligible land, agriculture plus forestry, would be expected to increase.

In sum, differential assessment is expected to increase total eligible land acreage, ceteris

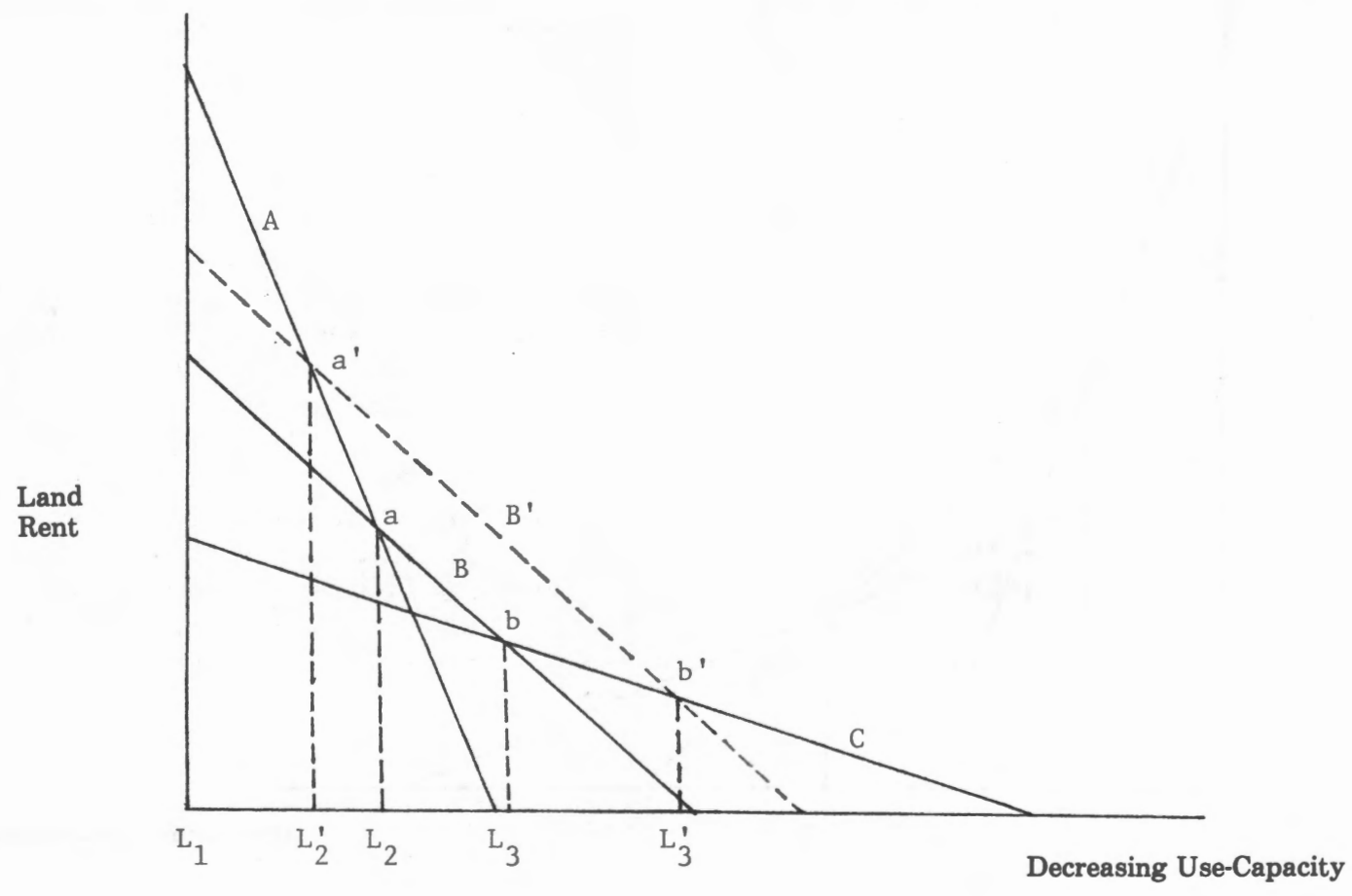

Figure 3. The Effect of Differential Assessment on Agriculture. 


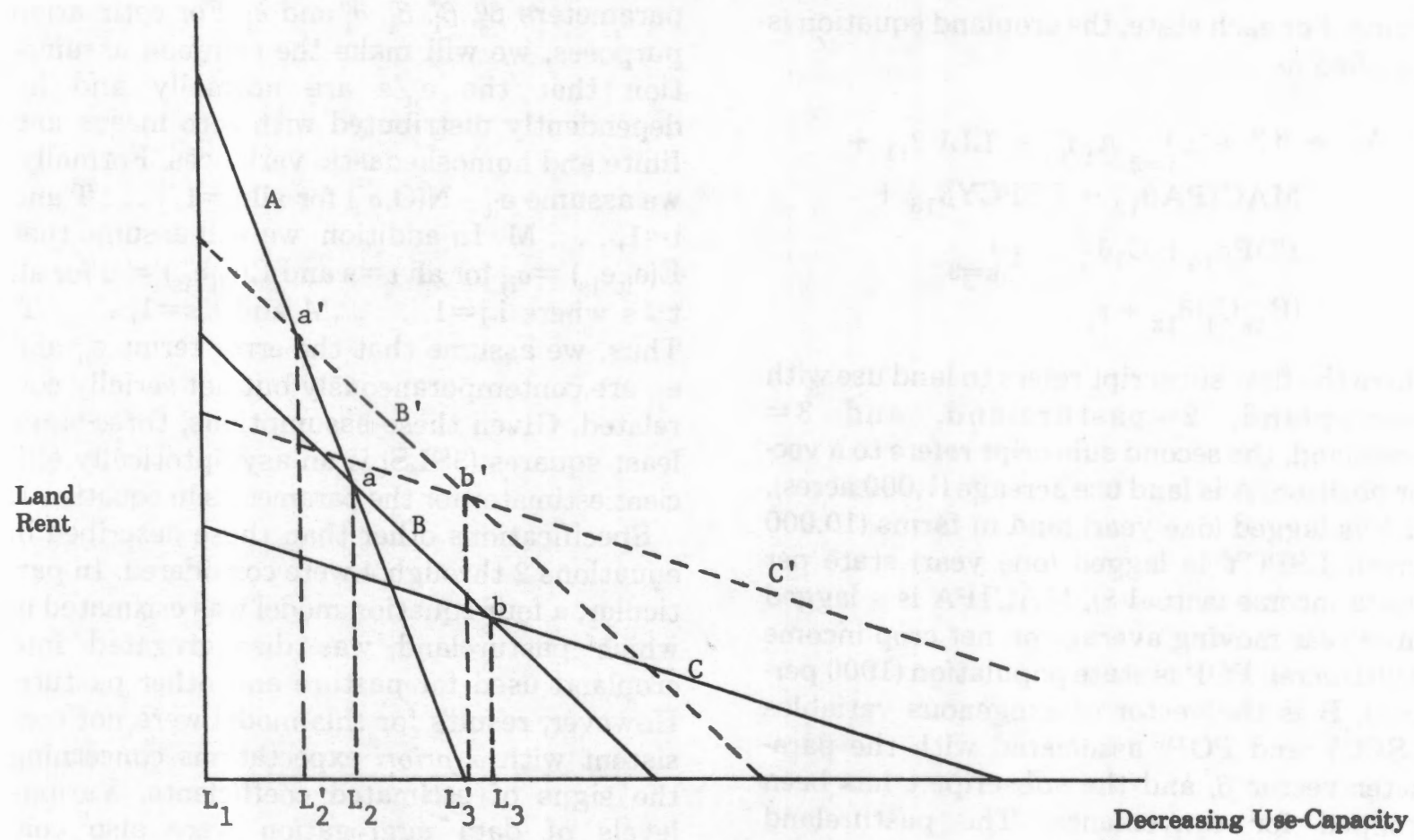

Figure 4. The Effect of Differential Assessment on Eligible Land Uses.

paribus. ${ }^{2}$ However, ex post acreages for different competing eligible land uses may increase or decrease depending on net margin of transference effects. An important implication of this result is that an empirical model describing eligible land uses and differential assessment should account for the simultaneity between competing eligible land use alternatives. In the next section, a simultaneous equation model that accounts for net margin of transference effects is discussed.

\section{Empirical Model}

To investigate the effect of differential assessment legislation on eligible land use, a simultaneous equation acreage model similar to that of White and Fleming is used. Consider the state-level model,

$$
\begin{aligned}
& \text { (1) } A_{i t}=\beta_{i}^{0}+A_{i t}^{*} \beta_{i}^{*}+B_{i t} \beta_{i}+\quad i=1, \ldots M \\
& C_{i t} \partial_{i}^{o}+B_{i t} C_{i t} \partial_{i}+e_{i t} \text {, } \\
& \mathrm{t}=1, \ldots \mathrm{T}
\end{aligned}
$$

where $A_{i t}$ is acreage of eligible land use $i$ in year $t, A_{i t}$ is a vector of competing eligible land use acreages, $B_{i t}$ is a vector of $\mathbf{K}$ exogenous variable values, $C_{i t}$ is a dummy variable that is equal to one upon enactment of differential assessment and zero otherwise, $\beta_{i}^{0}$ and $\partial_{i}^{o}$ are parameters, $\beta_{i}^{*}, \beta_{i}$, and $\partial_{i}^{\rho}$ are conformable parameter vectors, and $e_{i t}$ is a random error term.

The terms $\partial_{i}^{o}$ and $\partial_{j}$ describe the ex post effect of differential assessment on the parameters $\beta_{i}^{\circ}$ and $\beta_{i}$ respectively. Statistically, one can test the null hypothesis of no ex post effect by testing whether or not $\partial_{i}$ and $\partial_{i}^{0}$ are different from zero. Such a test would be two-tailed since, as mentioned in the previous section, margin of transference shifts are not unambiguously clear and could lead to positive or negative ex post effects for a particular eligible land use. In addition, the magnitude of any structural shifts due to differential assessment can be examined through $\partial_{i}^{0}$ and $\partial_{i}$. Although models more flexible than equation 1 can be envisioned, such a model seems sufficiently general to test and assess the impact of differential assessment on state eligible land use acreages.

\section{Specification}

For the 13 Southern states with differential assessment laws (Georgia, which enacted its law in 1983, was excluded), cropland, pastureland, and forestland are eligible under all pro- 
grams. For each state, the cropland equation is specified as:

(2) $\mathrm{A}_{1}=\beta_{1}^{0}+\Sigma_{j=2}^{3} \mathrm{~A}_{\mathrm{j}} \beta_{\mathrm{i} j}^{*}+\mathrm{LLF} \beta_{11}+$ MACIPA $\beta_{12}+\operatorname{LSPCY}_{13}+$ $\mathrm{POP} \beta_{14}+\mathrm{C}_{1} \partial_{1}^{0}+\Sigma_{\mathrm{k}=3}^{4}$

$\left(B_{1 k} C_{1}\right) \partial_{1 k}+e_{1}$

where the first subscript refers to land use with $1=$ cropland, $2=$ pastureland, and $3=$ forestland, the second subscript refers to a vector position, $A$ is land use acreage (1,000 acres), LLF is lagged (one year) land in farms $(10,000$ acres), LSPCY is lagged (one year) state per capita income (actual \$), MACIPA is a lagged three year moving average on net crop income (\$.001/acre), POP is state population (1000 persons), $B$ is the vector of exogenous variables (LSPCY and POP) associated with the parameter vector $\beta$, and the subscript $t$ has been dropped for convenience. The pastureland equation is specified as follows:

$$
\text { (3) } \begin{aligned}
\mathrm{A}_{2}= & \beta_{2}^{o}+\Sigma_{j=1, j \neq 2}^{3} \mathrm{~A}_{\mathrm{j}} \beta_{2 \mathrm{j}}^{*}+\mathrm{LLF} \beta_{21}+ \\
& \text { MALIPA } \beta_{22}+\operatorname{LSPCY} \beta_{23}+ \\
& \text { POP } \beta_{24}+\mathrm{C}_{2} \partial_{2}^{o}+\Sigma_{k=3}^{4} \\
& \left(\mathrm{~B}_{2 \mathrm{k}} \mathrm{C}_{2}\right) \partial_{2 \mathrm{k}}+\mathrm{e}_{2}
\end{aligned}
$$

where MALIPA is a lagged three year moving average on net livestock income (\$/acre) and all other terms are defined as above. The forestland equation is:

$$
\begin{aligned}
& \text { (4) } A_{3}=\beta_{3}^{0}+\Sigma_{j=1}^{2} A_{j} \beta_{3 j}^{*}+L L F \beta_{31}+ \\
& \text { MAPTIMB } \beta_{32}+\text { LSPCY } \beta_{33}+ \\
& \mathrm{POP} \beta_{34}+\mathrm{C}_{3} \partial_{3}^{o}+\Sigma_{\mathrm{k}=3}^{4} \\
& \left(\mathrm{~B}_{3 \mathrm{k}} \mathrm{C}_{3}\right) \partial_{3 \mathrm{k}}+\mathrm{e}_{3}
\end{aligned}
$$

where MAPTIMB is a three year moving average on the price of timber. ${ }^{3}$ For all equations, variables reflecting returns to a particular land use were expressed in terms of moving averages based on the notion that land use decisions would be affected by a history of past returns rather than returns for any particular year.

\section{Statistical Considerations}

Given the empirical model described above, our statistical problem is to estimate the parameters $\beta_{\mathrm{i}}^{o}, \beta_{\mathrm{i}}^{*}, \beta_{\mathrm{i}}, \partial_{\mathrm{i}}$ and $\partial_{\mathrm{i}}$. For estimation purposes, we will make the common assumption that the $e_{i t}$ 's are normally and independently distributed with zero means and finite and homoskedastic variances. Formally, we assume $e_{i t} \sim N\left(0, \sigma_{i}^{2}\right)$ for all $t=1, \ldots, T$ and $\mathrm{i}=1, \ldots, \mathrm{M}$. In addition, we will assume that $E\left(e_{i t} e_{j s}\right)=\sigma_{i j}$ for all $t=s$ and $E\left(e_{i t} e_{j s}\right)=0$ for all $t \neq s$ where $i, j=1, \ldots, M$ and $t, s=1, \ldots, T$. Thus, we assume that the error terms $e_{i t}$ and $\mathbf{e}_{j \mathrm{t}}$ are contemporaneously but not serially correlated. Given these assumptions, three-stage least squares (3SLS) is an asymptotically efficient estimator for the parameters in equation 1.

Specifications other than those described in equations 2 through 4 were considered. In particular, a four equation model was estimated in which pastureland was disaggregated into cropland used for pasture and other pasture. However, results for this model were not consistent with a priori expectations concerning the signs of estimated coefficients. Various levels of data aggregation were also considered. First, equations 2 through 4 were estimated for each of the 14 Southern states. Next, a pooled model for the Southern region (all 14 states) was estimated. Results for these two models were less than satisfactory for the following reasons. For the state-level model, estimated parameter values fluctuated widely from state to state. Such a result was likely due to lack of a sufficiently long time-series before and after the passage of differential assessment legislation. Indeed, for some states that recently adopted differential assessment, only two or three ex post observations were available. To overcome this degrees of freedom problem, a regional-level model was estimated. However, given the wide disparity between the Southern states with regard to agriculture, topography, climate, and urbanization, a regional-level model suffers from obvious aggregation error.

As a compromise solution, it was decided to selectively pool the states into subregional groups such that states included within any particular group would be reasonably homogeneous with respect to size, topography, agriculture, etc. An appropriate pooling criterion appeared to be the USDA's ten farm production regions for the U.S. The four Southern farm production regions are shown in Figure 5. Pooling the states into these subregions permitted a gain in degrees of freedom with a minimum level of aggregation. The 


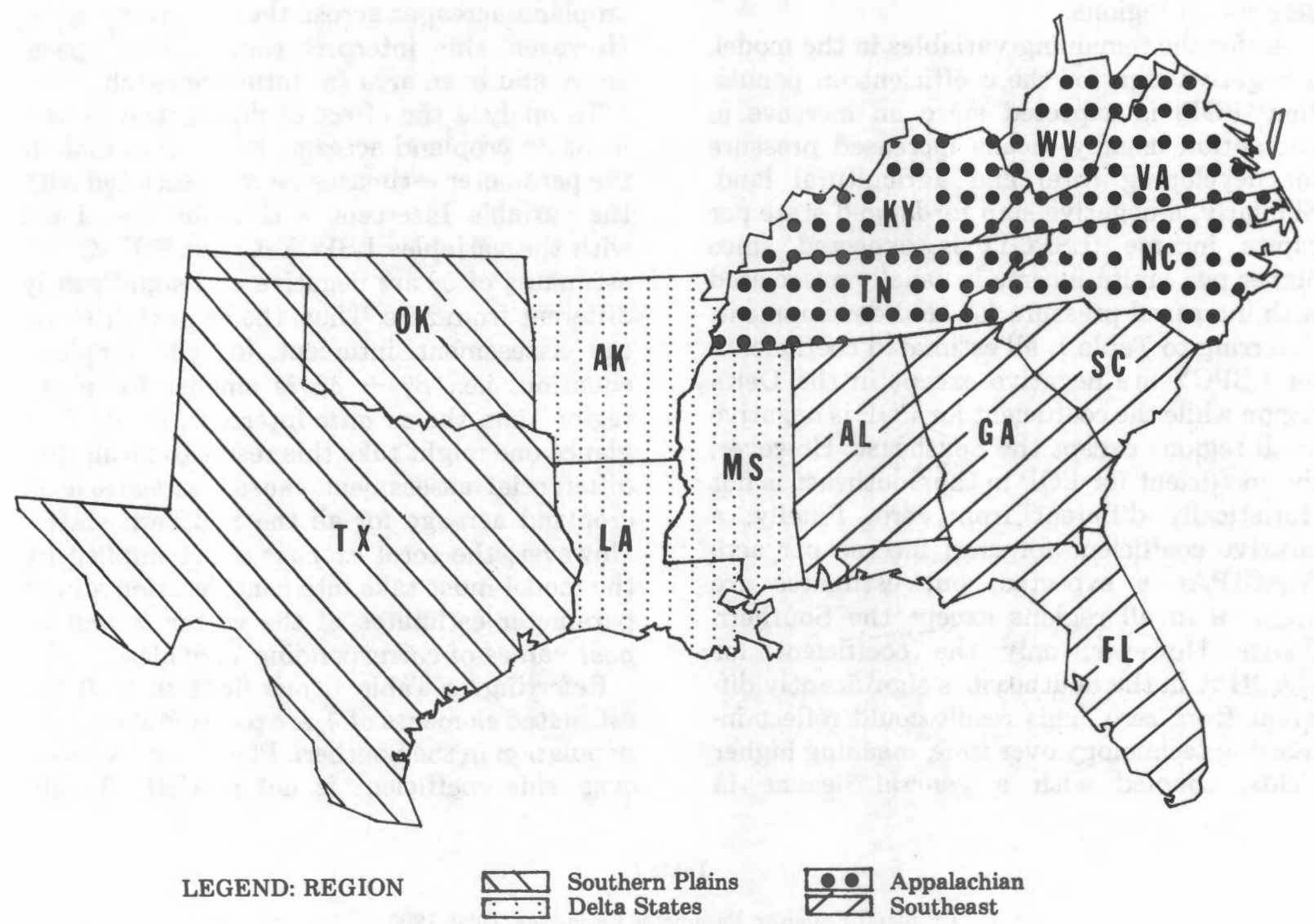

Figure 5. Southern Farm Production Regions.

trade-off between the subregional model and the state-level model is that the subregional model assumes that $\beta_{\mathrm{i}}^{\circ}, \beta_{\mathrm{i}}^{*}, \beta_{\mathrm{i}}, \partial_{\mathrm{i}}^{\mathrm{o}}$, and $\partial_{\mathrm{i}}$ are the same across states within the subregion. Thus, the subregional model uses individual state data and is a restricted version of the statelevel model.
1950-1980 period. Additional data used in the analysis were land in farms, state per capita income, population, crop income, livestock income, and timber prices. ${ }^{4}$

\section{Parameter Estimates}

Three-stage least squares results for the 
zero for all regions.

As for the remaining variables in the model, a negative sign for the coefficient on population (POP) is expected since an increase in population usually means increased pressure for developing rural and agricultural land. Similarly, a negative sign for lagged state per capita income (LSPCY) is expected since higher per capita income is usually associated with increased pressure for land development. Referring to Table 1, all estimated coefficients for LSPCY are negative except in the Delta region while the coefficient for $P O P$ is negative in all regions except the Southeast. However, the coefficient for POP in the Southeast is not statistically different from zero. Finally, a positive coefficient for crop income per acre (MACIPA) is expected, but estimates are negative in all regions except the Southern Plains. However, only the coefficient for MACIPA in the Southeast is significantly different from zero. This result could reflect increasing technology over time, meaning higher yields, coupled with a general decline in cropland acreages across the Southern region. However, this interpretation is very speculative and is an area for future research.

To analyze the effect of differential assessment on cropland acreage, we need to look at the parameter estimates for $\partial_{1}$, associated with the variable Intercept $\bullet \mathrm{C}$, and $\partial_{1}$ associated with the variables LSPCY $\cdot C$ and POP.C. All estimates of $\partial_{1}^{o}$ are negative and significantly different from zero. Thus, the ex post differential assessment intercept for the cropland equation, i.e., $\beta_{1}^{0}+\partial_{1}^{0}$, is smaller for every region than the ex ante intercept, $\beta_{1}^{o}$. At first glance one might take this result to mean that differential assessment caused a decrease in cropland acreage for all the Southern states. However, the total ex post effect implied by the model must take into consideration all the parameter estimates of the vector $\partial_{1}$ and $e x$ post values of corresponding variables.

Referring to Table 1, one finds that all the estimated elements of $\partial_{1}$ are positive except for population in the Southern Plains region. However, this coefficient is not statistically dif-

Table 1

Cropland Equation Parameter Estimates, 1950-1980

\begin{tabular}{lcccc}
\hline \hline & & \multicolumn{2}{c}{ Parameter Estimates } & \\
\cline { 3 - 5 } Variable & Appalachian & Delta & Southeast & Southern Plains \\
\hline Intercept & -487.5939 & 1554.8850 & 978.3063 & 4794.1570 \\
& $(171.1295)^{* *}$ & $(1204.1460)$ & $(202.1727)^{* *}$ & $(1806.4750)^{* *}$ \\
Pastureland & -.6269 & .7694 & -.9208 & -.5361 \\
& $(.0387)^{* *}$ & $(.1895)^{* *}$ & $(.0459)^{* *}$ & $(.1983)^{* *}$ \\
Forestland & -.4392 & -.7619 & -.6144 & -.9016
\end{tabular}


Table 2

Pastureland Equation Parameter Estimates, 1950-1980

\begin{tabular}{|c|c|c|c|c|}
\hline \multirow[b]{2}{*}{ Variable } & \multirow[b]{2}{*}{ Appalachian } & \multicolumn{2}{|c|}{ Parameter Estimates } & \multirow[b]{2}{*}{ Southern Plains } \\
\hline & & Delta & Southeast & \\
\hline Intercept & $\begin{array}{l}-14.4506 \\
(258.7454)\end{array}$ & $\begin{array}{c}-208.9179 \\
(728.6868)\end{array}$ & $\begin{array}{l}865.1352 \\
(257.4068)^{* *}\end{array}$ & $\begin{array}{c}-5801.1400 \\
(1211.7990)^{* *}\end{array}$ \\
\hline Cropland & $\begin{array}{l}-1.2902 \\
(.0828)^{* *}\end{array}$ & $\begin{array}{l}.3359 \\
(.0657)^{* *}\end{array}$ & $\begin{array}{l}-.9257 \\
(.0571)^{* *}\end{array}$ & $\begin{array}{l}.1603 \\
(.1532)\end{array}$ \\
\hline Forestland & $\begin{array}{l}-.8290 \\
(.0470)^{* *}\end{array}$ & $\begin{array}{c}-.0058 \\
(.0784)\end{array}$ & $\begin{array}{l}-.8081 \\
(.0635)^{* *}\end{array}$ & $\begin{array}{l}-.7439 \\
(.1178)^{* *}\end{array}$ \\
\hline LLF & $\begin{array}{l}9.4091 \\
(.2856)^{* * *}\end{array}$ & $\begin{array}{l}.9823 \\
(.4934)^{* * *}\end{array}$ & $\begin{array}{l}7.3465 \\
(.4125)^{* * *}\end{array}$ & $\begin{array}{l}6.3009 \\
(.7182)^{* *}\end{array}$ \\
\hline MALIPA & $\begin{array}{c}-.7363 \\
(.3925)^{*}\end{array}$ & $\begin{array}{l}10.5063 \\
(4.3669)^{* *}\end{array}$ & $\begin{array}{l}-.1672 \\
(1.2866)\end{array}$ & $\begin{array}{r}-248.4411 \\
(53.6487)^{* *}\end{array}$ \\
\hline LSPCY & $\begin{array}{c}-.2158 \\
(.0668)^{* *}\end{array}$ & $\begin{array}{l}-.8157 \\
(.1880)^{* *}\end{array}$ & $\begin{array}{l}-.2871 \\
(.1077)^{* *}\end{array}$ & $\begin{array}{l}2.4261 \\
(.6956)^{*}\end{array}$ \\
\hline POP & $\begin{array}{l}.0146 \\
(.0716)\end{array}$ & $\begin{array}{l}.8117 \\
(.1862)^{* *}\end{array}$ & $\begin{array}{c}.0382 \\
(.1270)\end{array}$ & $\begin{array}{l}1.7397 \\
(.6186)^{* * *}\end{array}$ \\
\hline Intercept $\cdot \mathbf{C}$ & $\begin{array}{l}-2651.8500 \\
(528.3456)^{* *}\end{array}$ & $\begin{array}{r}-104.9837 \\
(563.8848)\end{array}$ & $\begin{array}{c}-1001.3000 \\
(548.5698)^{*}\end{array}$ & $\begin{array}{c}6850.5780 \\
(3522.9680)^{*}\end{array}$ \\
\hline LSPCY • C & $\begin{array}{l}.6241 \\
(.0878)^{* *}\end{array}$ & $\begin{array}{r}-.0890 \\
(.1267)\end{array}$ & $\begin{array}{l}.3443 \\
(.0832)^{* *}\end{array}$ & $\begin{array}{r}-.8837 \\
(.6622)\end{array}$ \\
\hline POP - C & $\begin{array}{l}.0236 \\
(.0851)\end{array}$ & $\begin{array}{c}.0921 \\
(.2637)\end{array}$ & $\begin{array}{c}-.0817 \\
(.1353)\end{array}$ & $\begin{array}{c}-.7051 \\
(.1867)^{* *}\end{array}$ \\
\hline
\end{tabular}

* Statistically different from zero, 95 percent significance level.

*Statistically different from zero, 90 percent significance level. 
Table 3

Forestland Equation Parameter Estimates, 1950-1980

\begin{tabular}{|c|c|c|c|c|}
\hline \multirow[b]{2}{*}{ Variable } & \multicolumn{4}{|c|}{ Parameter Estimates } \\
\hline & Appalachian & Delta & Southeast & Southern Plains \\
\hline Intercept & $\begin{array}{c}631.6688 \\
(279.7054)^{* *}\end{array}$ & $\begin{array}{r}-429.7693 \\
(950.1865)\end{array}$ & $\begin{array}{l}655.5930 \\
(272.4964)^{* *}\end{array}$ & $\begin{array}{c}-1612.8500 \\
(1615.7280)\end{array}$ \\
\hline Cropland & $\begin{array}{l}-1.0905 \\
(.1298) * *\end{array}$ & $\begin{array}{l}-.5330 \\
(.0846)^{* *}\end{array}$ & $\begin{array}{l}-.9804 \\
(.0804)^{* *}\end{array}$ & $\begin{array}{l}-.3097 \\
(.1885)\end{array}$ \\
\hline Pastureland & $\begin{array}{l}-.9715 \\
(.0550)^{* *}\end{array}$ & $\begin{array}{c}.1277 \\
(.1584)\end{array}$ & $\begin{array}{l}-1.0416 \\
(.0709)^{* *}\end{array}$ & $\begin{array}{l}-.6080 \\
(.0751)^{* *}\end{array}$ \\
\hline LLF & $\begin{array}{l}8.7890 \\
(.6455)^{* *}\end{array}$ & $\begin{array}{l}5.5658 \\
(.3609)^{* *}\end{array}$ & $\begin{array}{l}8.4476 \\
(.2974)^{* *}\end{array}$ & $\begin{array}{l}7.2516 \\
(.2327)^{* *}\end{array}$ \\
\hline MAPTIMB & $\begin{array}{c}2.0774 \\
(2.1689)\end{array}$ & $\begin{array}{l}10.1361 \\
(4.2983)^{* *}\end{array}$ & $\begin{array}{l}10.0427 \\
(4.7913)^{* *}\end{array}$ & $\begin{array}{c}13.2205 \\
(22.5147)\end{array}$ \\
\hline LSPCY & $\begin{array}{l}-.4493 \\
(.0719)^{* *}\end{array}$ & $\begin{array}{l}-.6856 \\
(.1306)^{* *}\end{array}$ & $\begin{array}{l}-.5977 \\
(.1021)^{* *}\end{array}$ & $\begin{array}{r}-.6472 \\
(.5361)\end{array}$ \\
\hline POP & $\begin{array}{l}.1666 \\
(.0777)^{* *}\end{array}$ & $\begin{array}{c}-.2253 \\
(.2123)\end{array}$ & $\begin{array}{l}.1460 \\
(.1312)\end{array}$ & $\begin{array}{l}-2.0294 \\
(.4070)^{* *}\end{array}$ \\
\hline Intercept $\cdot \mathbf{C}$ & $\begin{array}{l}-2505.5500 \\
(577.0943)^{* *}\end{array}$ & $\begin{array}{l}-3617.9400 \\
(515.5654)^{* *}\end{array}$ & $\begin{array}{c}-485.7568 \\
(502.9039)\end{array}$ & $\begin{array}{l}-6700.0900 \\
(1660.9270)^{* *}\end{array}$ \\
\hline LSPCY • C & $\begin{array}{l}.7530 \\
(.0858)^{* *}\end{array}$ & $\begin{array}{l}.7457 \\
(.1068)^{* *}\end{array}$ & $\begin{array}{l}.4098 \\
(.0754)^{* *}\end{array}$ & $\begin{array}{l}1.1282 \\
(.3463)^{* *}\end{array}$ \\
\hline POP $\cdot \mathrm{C}$ & $\begin{array}{c}-.1494 \\
(.0918)\end{array}$ & $\begin{array}{c}.2279 \\
(.2011)\end{array}$ & $\begin{array}{l}-.2640 \\
(.1308)^{* *}\end{array}$ & $\begin{array}{c}-.4093 \\
(.1030)^{* *}\end{array}$ \\
\hline
\end{tabular}

**Statistically different from zero, 95 percent significance level.

*Statistically different from zero, 90 percent significance level.

ferent from zero. To derive the ex post differential assessment coefficients for LSPCY and POP, we merely add the appropriate value from $\partial_{1}$ to the ex ante coefficients discussed above. Thus, for example, given the ex ante coefficient on population in the Delta region of -1.0897 , we can derive the ex post coefficient as $-1.0897+.5994=-.4903$. However, we cannot interpret these ex ante and ex post structural coefficients as the total effect of a change in population on cropland since the cropland equation is part of a simultaneous equation system. That is, a change in population affects pastureland and forestland acreages (i.e., the other endogenous variables in the model) which in turn affect cropland acreage. These interlinkages can be accounted for by considering regional multipliers for the system which are discussed in the next section.

Results for the pastureland and forestland equations are presented in Tables 2 and 3. Expectations regarding signs of estimated coefficients are much the same as for the cropland equation. Except for a few cases, signs on all coefficients for the substitute acreage variables are negative as expected. The coefficient for lagged land in farms (LLF) is positive and significantly different from zero in both equations for all four regions. As in the cropland equation, interpretation of the coefficients for population and lagged state per capita income involves consideration of ex ante and ex post differential assessment effects. Thus, evaluation of the effect of these variables on eligible land use will be addressed in the next section on post model analysis. System $\mathrm{R}^{2}$ 's for all fitted equations were generally high, ranging from .95 for the Delta region to .99 for the Southern Plains region. ${ }^{5}$

\section{Multipliers}

Since the relationships expressed in equations 2 through 4 constitute a simultaneous system of equations, the structural coefficients (i.e., the $\beta$ 's and $\partial$ 's) cannot directly be interpreted as the marginal effect of exogenous variable changes on the endogenous variables in 
the model. To obtain the direct and indirect effects of the exogenous variables on the endogenous variables, we must solve the system explicitly in the endogenous variables; that is, we must derive the reduced-form of the system. Specifically, our interest lies in finding the impact of a change in one of the exogenous variables, say $x_{i}$, on one of the endogenous variables, say $y_{j}$, or mathematically: $d y_{j} / d x_{i}$ where $i=1, \ldots, K$ and $j=l, \ldots, M$ (see equation 1). $E x$ ante differential assessment, $\mathrm{dy}_{\mathrm{j}} / \mathrm{dx}_{\mathrm{i}}$ will involve our estimates of the $\beta$ 's. In addition, $e x$ post differential assessment, $\mathrm{dy}_{\mathrm{j}} / \mathrm{dx}_{\mathrm{i}}$ will involve our estimates of the $\partial$ 's. The resulting estimates of $\mathrm{dy}_{\mathrm{j}} / \mathrm{dx}_{\mathrm{i}}$ are called the multipliers of the system.

For our purposes, of particular interest are the ex ante and ex post multipliers for per capita income (LSPCY) and population (POP). Such an interest stems from the hypothesis that if differential assessment legislation were effective in preserving eligible land, one would expect ex post multipliers to reflect a lessened impact on at least some eligible land use acreages given changes in population and/or income. ${ }^{6}$ $E x$ ante and ex post population and income multipliers for the four Southern regions are presented in Table 4.

As an example of interpreting the results in Table 4, consider the ex ante and ex post income multipliers for cropland in the Appalachian region. The ex ante multiplier is -.1100 , implying a $\$ 100$ increase in state per capita income decreases cropland acreage by about 11,000 acres, while the ex post multiplier is -.0724 , implying a $\$ 100$ increase in state per capita income decreases cropland by only about 7, 240 acres. Thus, higher incomes, which are often associated with increased demand for aesthetic goods, appear to bring about relatively less conversion of cropland (ex post differential assessment) in the Appalachian region. Cropland is an eligible land use under all Southern differential assessment programs. Results for the population multipliers can be interpreted similarly. For example, in the Southern Plains region, ex ante differential assessment, a 1,000 person increase in state population resulted in approximately a 6,420 acre decrease in forestland. However, ex post differential assessment, a 1,000 person increase in population implies a 5,281 decrease in forestland acres, or about 1,200 acres less than before the passage of differential assessment legislation. Hence, in these two examples, it appears that differential assessment was successful in preserving eligible land acreage.

Study of Table 4 reveals that for income the $e x$ ante multiplier is less than the ex post differential assessment multiplier in 8 out of 12 cases. ${ }^{7}$ Specifically, the ex post income multiplier was greater for forestland for all regions and greater for both cropland and pastureland in two regions. In the Southern Plains Region, the ex post income multiplier was greater for all three eligible land uses. Thus, one might contend that differential assessment could provide a successful vehicle

Table 4

Regional Income and Population Multipliers Ex ante and Ex post Differential Assessment

\begin{tabular}{|c|c|c|c|c|c|c|}
\hline \multirow[b]{2}{*}{ Region } & \multicolumn{2}{|c|}{ Cropland } & \multicolumn{2}{|c|}{ Pastureland } & \multicolumn{2}{|c|}{ Forestland } \\
\hline & Income & Population & Income & Population & Income & Population \\
\hline $\begin{array}{l}\text { Appalachian: } \\
\text { Ex ante } \\
\text { Ex post }\end{array}$ & $\begin{array}{l}-.1100 \\
-.0724^{*}\end{array}$ & $\begin{array}{r}.0783 \\
-.2148\end{array}$ & $\begin{array}{r}1.0184^{*} \\
.9428^{*}\end{array}$ & $\begin{array}{r}-.7877 \\
.5480\end{array}$ & $\begin{array}{l}-1.3179^{*} \\
-.5325^{*}\end{array}$ & $\begin{array}{c}.8464^{*} \\
-.2798\end{array}$ \\
\hline $\begin{array}{l}\text { Delta: } \\
\text { Ex ante } \\
\text { Ex post }\end{array}$ & $\begin{array}{l}.5897^{*} \\
.0896^{*}\end{array}$ & $\begin{array}{r}-1.0179^{*} \\
.3092^{*}\end{array}$ & $\begin{array}{l}-.6114^{*} \\
-.8743\end{array}$ & $\begin{array}{c}.4677^{*} \\
1.0081\end{array}$ & $\begin{array}{l}-1.0786^{*} \\
-.0997^{*}\end{array}$ & $\begin{array}{r}.3774 \\
-.0328\end{array}$ \\
\hline $\begin{array}{l}\text { Southeast: } \\
\text { Ex ante } \\
\text { Ex post }\end{array}$ & $\begin{array}{l}-.6445 \\
-.6781^{*}\end{array}$ & $\begin{array}{r}.4989 \\
1.2162\end{array}$ & $\begin{array}{l}1.7882^{*} \\
1.8972^{*}\end{array}$ & $\begin{array}{l}-.9294 \\
-.7075\end{array}$ & $\begin{array}{l}-1.8297^{*} \\
-1.5003^{*}\end{array}$ & $\begin{array}{c}.6255 \\
-.5727 *\end{array}$ \\
\hline $\begin{array}{l}\text { Southern Plains: } \\
\text { Ex ante } \\
\text { Ex post }\end{array}$ & $\begin{array}{c}-1.5874^{*} \\
2.2473\end{array}$ & $\begin{array}{r}1.0538 \\
.9766\end{array}$ & $\begin{array}{l}4.1765^{*} \\
5.2951\end{array}$ & $\begin{array}{l}6.6854^{*} \\
5.3430^{*}\end{array}$ & $\begin{array}{r}-2.6942 \\
.4488\end{array}$ & $\begin{array}{l}-6.4204^{*} \\
-5.2808^{\circ}\end{array}$ \\
\hline
\end{tabular}

*Based on statistically significant coefficients for income and population variables. 
for the realization of aesthetic demands for forestland (as reflected by higher per capita incomes) in the South, but not unambiguously so for pastureland and cropland (where ex post multipliers indicated mixed effects). However, in these latter cases it should be kept in mind that tax relief, especially to farmers, is an objective of differential assessment, in addition to preserving eligible land for aesthetic reasons. Finally, one should be cautious in interpreting multipliers based on statistically insignificant income and population coefficients (those without asterisks in Table 4).

Results for the population multipliers, ex ante and ex post differential assessment, suggest that in general, differential assessment legislation in the South has not been effective in dampening the impact of population pressure on forestland acreage. The ex post population multiplier for forestland was greater only in the Southern Plains region. For cropland, the ex post population multiplier was greater in the Delta and Southeast regions while the multiplier for pastureland was greater in all regions except the Southern Plains. Overall, the ex post population multiplier was larger than the ex ante multiplier in 6 out of 12 cases.

In sum, results indicate that with respect to the effect of income on eligible land use acreages, differential assessment appears to have been most effective in the Southern Plains region. For this region, ex post multipliers were greater than their ex ante counterparts for all three eligible land uses. For all other regions, only one or two eligible land uses exhibited greater ex post income multipliers. With regard to population, no region had greater ex post multipliers for all three eligible land uses. The mixed nature of these results implies that differential assessment has not had an unambiguous effect on total eligible land acreage nor can we conclude that it had clear effects upon any specific major eligible land use category in the Southern states. ${ }^{8}$

\section{Summary}

We have considered a subregional model of categorical land use acreages generally included as "eligible" under state differential assessment programs in the South. The model is constructed upon the basic theory of land rent profiles. Given this theoretical framework, differential assessment, if successful, is expected to alter eligible land use rent profiles such that total ex post eligible land acreage would be greater than if differential assessment had not occurred. In this case, although the total acreage should increase, any particular categorical eligible land use acreage may decline due to net margin of transference effects resulting from land rent profile shifts.

Results of the model indicated that differential assessment in the South has not been generally successful in forestalling the conversion of eligible land to non-eligible uses. However, for eligible land uses in some regions of the South, results implied that the ex post effect of population was dampened by differential assessment. This result occurred primarily for cropland and pastureland. In terms of the effect of income on eligible land acreages, ex post impact multipliers suggested differential assessment was effective in preserving all eligible land acreages in the Southern Plains, cropland and forestland in the Appalachian region, pastureland and forestland in the Southeast, and forestland in the Delta region.

\section{FOOTNOTES}

\begin{abstract}
${ }^{1}$ However, as one reviewer notes, land which is already developed for urban use is subject to expensive reconversion costs. Thus, little conversion to agricultural use would be expected in the short run. And, that reconversion which did occur would likely be undeveloped speculatively held urban land.

'This conclusion is based upon a simple comparative static analysis of land rent profile changes due to differential assessment. In a truly dynamic analysis, land rent profiles would be expected to change due to changes in demography, technology, economics, etc. However, after accounting for these factors differential assessment, if successful, would unambiguously be expected to alter land rent profiles such that total ex post eligible land acreage would be greater than if differential assessment had not occurred.

'For the period of analysis, 1950 through 1980, two differential assessment laws were passed in Texas. Under the 1966 law, only cropland and pastureland were considered eligible land uses while forestland became eligible under the 1978 law. Thus, the dichotomous variable $C_{i t}$ is defined differently in equation 4, relative to equations 2 and 3 , for the case of Texas. For all other states, cropland, pastureland, and forestland are eligible under all legislated differential assessment programs.

Annual planted acres of cropland by state were collected from tables compiled by the Crop Reporting Board, Statistical Reporting Service, U.S. Department of Agriculture, and annual summary issues of Crop Production published by the Crop Reporting Board. Crop acreage includes planted acreage for corn, sorghum, oats, barley, durum and other spring wheat, rice, soybeans, flaxseed, peanuts, sunflower seed, popcorn, cotton, dry edible beans, dry edible peas, potatoes, sweet potatoes, and sugar beets; and harvested acreage for winter wheat, rye, all hay, tobacco, and sugarcane.
\end{abstract}


Estimates of the acres of pastureland and forestland by state were collected from the U.S. Census of Agriculture, State and County Data, Bureau of the Census, U.S Department of Commerce. U.S. Census of Agriculture data were available for the years 1950, 1954, 1959, 1964, 1969,1974 , and 1978. A linear trend was used to estimate acres of pastureland and forestland for the non-census years. Total agricultural land eligible for differential assessment by state was estimated by aggregating the annual estimates of cropland, pastureland, and forestland.

State per capita income and state population were collected from Bureau of the Census, U.S. Department of Commerce, Statistical Abstract of the United States, annual editions, 1950-1980. Crop income (cash receipts from crops) and livestock income (cash receipts from livestock and products) were collected for each state from U.S. Department of Agriculture, Agricultural Statistics, annual editions, 1950-1980. Land in farms figures by state were collected from: Economic Research Service, U.S. Department of Agriculture, Farm Real Estate Historical Series Data: 1850-1970, ERS 520, June 1973 (for years 1950-1968); Crop Reporting Board, U.S. Department of Agriculture, Farms and Land in Farms, Final Estimates by States, 1969-75, Statistical Bulletin 594, December 1977 (for years 1969-1974); Crop Reporting Board, U.S. Department of Agriculture, Farm Numbers, December 1977 (for years 1975-1978); and Economic Analysis Division, Farm Credit Administration, Agricultural Situation Report, January, 1981 (for years 1979-1980). Average prices received for Southern Pine sawtimber stumpage (timber prices) were obtained from tables compiled by the Southern Forest Products Association, New Orleans, Louisiana. Timber prices are for trees cut from National Forest land.

${ }^{5} R^{2}$ is computed as in McElroy. System $R^{2}$ 's were .97 for the Appalachian region and .98 for the Southeast region.

${ }^{6}$ For some eligible land uses, the ex post impact of increases in population and income may be greater than the ex ante impact. The reason is that even if differential assessment is successful in preserving total eligible land, any particular eligible land use could be negatively affected due to net margin of transference effects (see Figure 4 and related discussion).

'This can be confusing when examining Table 4. A negative multiplier is greater when its ex post absolute value is smaller. This implies that there is less negative effect on acreage of land use as income and population in. crease once differential assessment has been implemented.

${ }^{8} \mathrm{~A}$ shortcoming of the analysis is that possible differences in land use impacts under different types of differential assessment laws (preferential assessment; deferred taxation; restrictive agreements) were not explored. This issue we leave for further research.

\section{REFERENCES}

Barlowe, R., 1978. Land Economics. Englewood Cliffs: Prentice-Hall.

Berry, D., and T. Plaut, 1978. " Retaining Agricultural Activities Under Urban Pressures: A Review of Land Use Conflicts and Policies." Policy Sciences, 9:153-178.

Coughlin, R. E., D. Berry, and T. Plaut, 1978. "Differential Assessment of Real Property as an Incentive to Open Space Preservation and Farmland Retention." $\mathrm{Na}$ tional Tax Journal, 31:165-179.

Hady, T. F. and A. G. Sibold, 1974. State Programs for the Differential Assessment of Farm and Open Space Land, Agricultural Economic Report No. 256, Economic Research Service, USDA, Washington, D.C.

Keene, J. C. et al., 1976. Untaxing Open Space: An Evaluation of the Effectiveness of Differential Assessment of Farms and Open Space. Regional Science Research Institute, Philadelphia, Pa.

McElroy, M. B. 1977. "Goodness of Fit for Seemingly Unrelated Regressions: Glahn's $\mathbf{R}_{\mathrm{y} \cdot \mathrm{x}}$ and Hoopers $r^{-2 " . ~ J o u r n a l ~ o f ~ E c o n o m e t r i c s, ~ 6: 381-387 . ~}$

Mark, S. M., and H. Yamauchi, 1982. "Agricultural Use Value Taxation and Farmlands Preservation: A Basic Inconsistency." Annals of Regional Science, 16:73-77.

National Agricultural Lands Study, 1981. Final Report. U.S. Department of Agriculture, Washington, D.C.

Rodgers, P. H. and G. H. Williams, 1983. A Survey of UseValue Assessment Laws in the South. Southern Rural Development Center, Mississippi State University, Series No. 53.

White, F. C., and F. N. Fleming, 1980. "An Analysis of Competing Agricultural Land Uses." Southern Journal of Agricultural Economics, 12(2):99-103. 